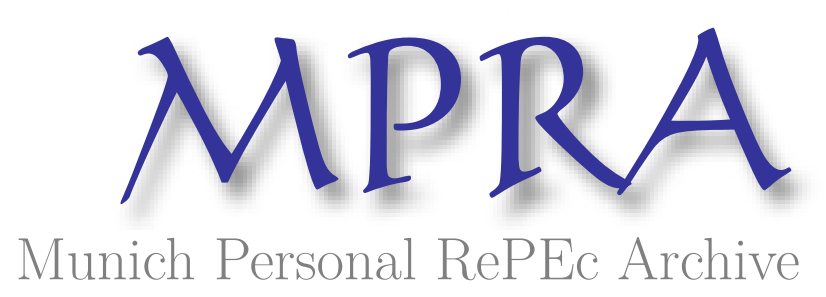

\title{
Extension in India by Public Sector Institutions: An Overview
}

Singh, K.M. and Meena, M.S. and Swanson, B.E.

ICAR-RCER, Patna, Zonal Project Directorate, Jodhpur, University of Illinois

14 August 2013

Online at https://mpra.ub.uni-muenchen.de/49107/

MPRA Paper No. 49107, posted 19 Aug 2013 11:18 UTC 


\title{
Extension in India by Public Sector Institutions: An Overview
}

\author{
K.M. Singh ${ }^{1}$, M.S. Meena ${ }^{2}$ and B.E. Swanson ${ }^{3}$
}

\begin{abstract}
Presently, Indian agricultural extension has wide mandates and despite the pluralistic extension approaches, its coverage and use of services is limited; particularly in rain-fed regions that are represented by marginal and smallholder farmers'. Hence, there is need to develop "need-based" capacity building of small-scale men and women farmers, as well as gaining access to reliable information in increasing their productivity and profitability for livelihoods improvements.

There are five major agricultural public sector extension systems devoted to extension work in India: (i) the Ministry of Agriculture at central level, including the Indian Council of Agricultural Research (ICAR) and the Directorate of Extension (DoE); (ii) State Departments of Agriculture (DoA), as well as the State Agricultural Universities (SAUs); (iii) the Departments of Agriculture (DoA), Animal Husbandry (DAH), Horticulture (DoH) and Fisheries (DoF), as well as the Krishi Vigyan Kendra (KVKs) and, more recently, the Agricultural Technology Management Agency (ATMA) at the District level; (iv) also, there are a wide variety of producers groups, including cooperatives and federations of milk, fruits, cotton, oilseeds, coconut, spices etc.; as well as (v) civil society organizations, such as the Non-governmental Organization (NGOs).

In agricultural innovation systems, there are still large gaps between research and extension approaches. Hence, there is need to evaluate the performance and socioeconomic impacts of research and extension programs. Also, a greater understanding of PPP is also required; including the mechanisms that help encourage partnerships. There is a want for a thorough evaluation of extension approaches in order to identify best practices and to understand their impact on farming communities in reaching small-scale and marginal farmers. The present study tries to analyse the role played by public sector institutions in India.
\end{abstract}

\footnotetext{
${ }^{1}$ Principal Scientist and Head, Division of Socio-Economics \& Extension, ICAR Research Complex for Eastern Region, Patna, India, Email: m.krishna.singh@gmail.com

${ }^{2}$ Principal Scientist (Agricultural Extension), Zonal Project Directorate, Jodhpur, India. Email: ms101@rediffmail.com

${ }^{3}$ Profesor Emeritus of Rural Development at the University of Illinois at Urbana Champaign.

Email: swansonb@illinois.edu
} 


\section{INTRODUCTION}

Extension has been traditionally funded, managed and delivered by the public sector all over the world. Agricultural extension in India has grown over last six decades. It is supported and funded by the national government-through its Ministry of Agriculture (MoA) and other allied ministries. The share of agriculture in Gross Domestic Product (GDP) has declined from over half at the time of independence to less than one-fifth this year. Indian agriculture sector has an impressive long-term record of taking the country out of serious food shortages despite rapid population increase, given its heavy reliance on the work of its pluralistic extension system.

There are five major agricultural extension systems devoted to extension work in India: (i) the Ministry of Agriculture at central level, including the Indian Council of Agricultural Research (ICAR) and the Directorate of Extension (DoE); (ii) State Departments of Agriculture (DoA), as well as the State Agricultural Universities (SAUs); (iii) the Departments of Agriculture (DoA), Animal Husbandry (DAH), Horticulture (DoH) and Fisheries (DoF), as well as the Krishi Vigyan Kendra (KVKs) and, more recently, the Agricultural Technology Management Agency (ATMA) at the District level; (iv) also, there are a wide variety of producers groups, including cooperatives and federations of milk, fruits, cotton, oilseeds, coconut, spices etc.; as well as (v) civil society organizations, such as the Non-governmental Organization (NGOs). An overview of this pluralistic extension system is depicted in Figure-2.1.

It should be noted that the main responsibility for extension activities rests with state governments, since agriculture is a state subject. The central government also implements several technology transfer plans through state governments. Also, Indian agriculture is becoming increasingly more pluralistic in nature, where a large number of private sector firms and civil society extension service providers (e.g. NGOs) co-exist with this public extension system.

\section{Department of Agriculture and Cooperation (DAC)}

The MoA comprises of Department of Agriculture and Cooperation (DAC) and the Department of Agricultural Research and Education (DARE). The Union Minister holds overall control over the MoA, assisted by Minister of State (Agriculture). The Secretary $(\mathrm{A} \& \mathrm{C})$ is administrative head of the Department and Principal Adviser to the Minister on all matters of policy and administration within the Department. DAC has implemented 12 schemes through DARE, 43 central sector schemes and 2 state plan schemes during eleventh five year plan. The DAC is responsible for formulation and implementation of national policies and programmes aimed at achieving rapid agricultural growth through optimum utilization of the country's land, water, soil and plant resources. 


\section{Figure-2.1: Agricultural Extension Systems in India.}

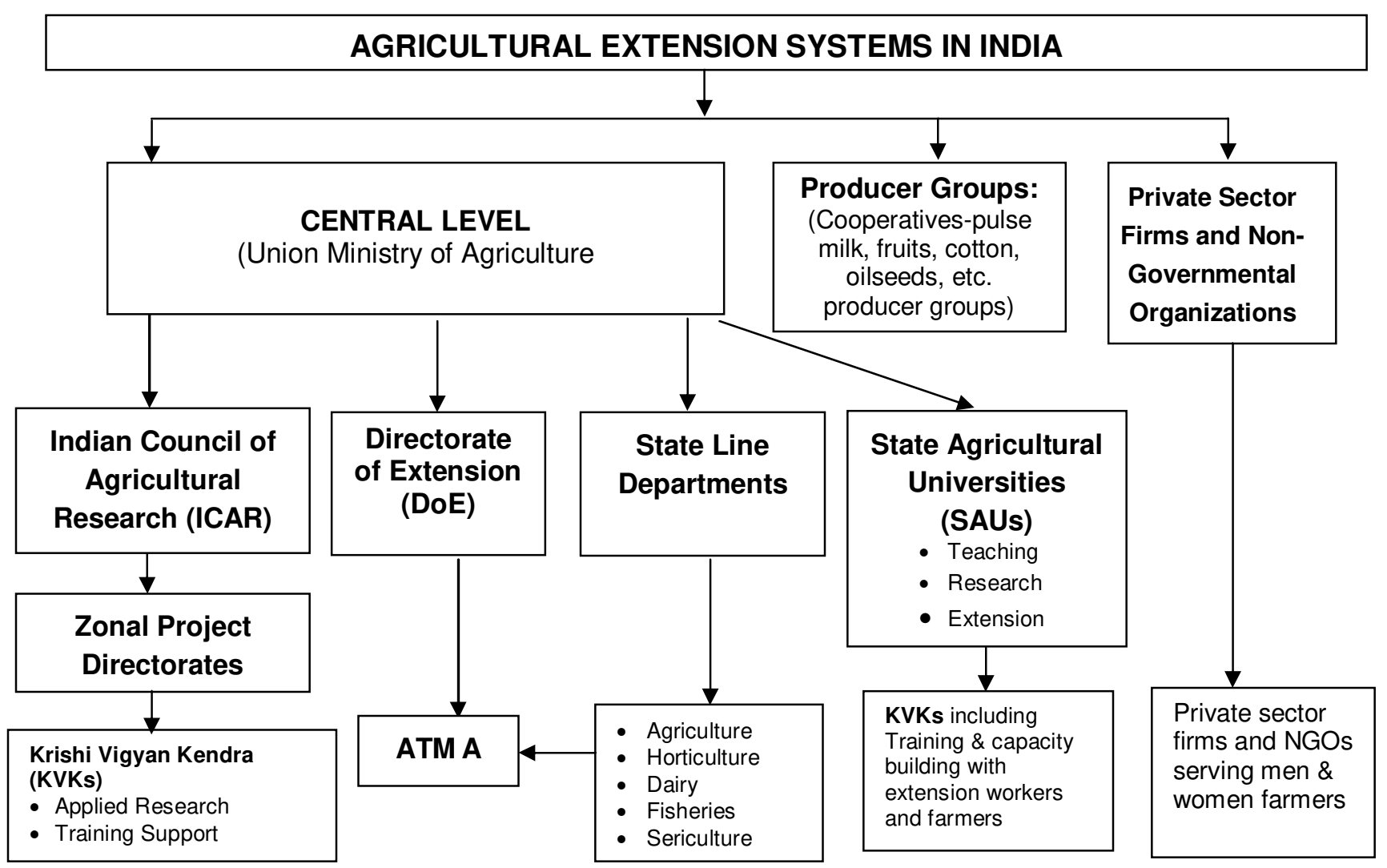

Source: Meena, M.S., K.M. Singh and B.E. Swanson

\section{Directorate of Extension}

The Directorate of Extension (DoE) within DAC was set up in 1958 for dissemination of specific knowledge to farmers, supervision of countrywide extension training infrastructure and to implement national programmes. Its role is essentially collaborative, providing guidance and technical support to the Extension Division. DoE executes its mandate through four units, including extension management, extension training, farm information and farm women development, plus the administrative unit. The first four correspond to these functional areas and fifth one is for administration support (Figure2.2).

Figure 2.2 Organizational Structure of Directorate of Extension

$$
\text { SECRETARY (DAC) }
$$<smiles>C1CC2CCC1C2</smiles> 
The major activities of agricultural extension at the district level are the assessment, refinement and demonstration of technology/products through a network of Krishi Vigyan Kendras (KVKs), the departments of agriculture, animal husbandry, horticulture, fisheries, etc. and the Agricultural Technology Management Agency (ATMA). Also, there are 44 Agricultural Technology Information Centres (ATIC) established under ICAR institutes and SAUs. There is one Directorate of Research on Women in Agriculture (DRWA) located in Bhubaneswar (Odisha). The Division is headed by Deputy Director General (DDG), Agricultural Extension supported by 2 Assistant Director Generals (ADGs). DARE, through the ICAR and the SAUs front-line extension system, plays a catalytic and supportive role by developing extension methodologies, refines and transfers front-line technologies and provides feedback to scientists. Achievements (http://www.icar.org.in/en/agricultural-extension.htm) of the division till December, 2012 are:

- Established a network of over $630 \mathrm{KVK}$.

- Conducted 4,189 on-farm trials (OFT) on 537 technologies to identify their location specificity under different farming systems.

- Organized 53,974 Front Line Demonstrations (FLD) to demonstrate production potential of newly released technologies on the farmers' fields.

- Trained more than 1.0 million farmers and extension personnel in agriculture and allied fields.

- Conducted large number of extension activities benefiting about 4.19 million farmers and other end users.

- Production of more than 82,000 qt. of seeds and 10.2 million sapling/seedlings/livestock strains, besides various bio-products for availability to the farmers.

- Identified gender issues in agriculture at DRWA for Women in Agriculture.

- Continued functioning of 44 ATICs in ICAR institutes and SAUs. 
- Organized 334 interface meetings involving scientists and development officials at district level.

\section{Department of Agricultural Research And Education (DARE)}

The DARE under MoA was established in December 1973 as a nodal department for all scientific and development related activities as well as bilateral scientific collaborations with other countries. The ICAR- a society registered under the Societies' Registration Act, 1860, is an organization under the DARE, with its headquarters in New Delhi, and a vast network for research all over the country. The Director General (DG) is the principal executive officer and is also the Secretary of DARE. The Governing Body, the chief executive and decision making authority, is chaired by the DG, which consists of eminent agricultural research and extension specialists.

DARE provides the necessary government linkages for ICAR, the premier research organization with a scientific strength of about 25,000 and a countrywide network of 49 institutes including 4 deemed to be of university-status, 6 national bureaus, 18 national research centres, 24 project directorates, 89 All-India Coordinated Research Projects (AICRPs) and 45 agricultural universities spread all over the country. Also providing agricultural education facilities through a very strong network of agricultural education system consisting of 3 Central Agricultural Universities (CAUs), another 2 CAUs have been proposed to be set up in the $12^{\text {th }}$ Five Year Plan (FYP), 45 SAUs and 5 national institutes of ICAR, deemed to be universities including National Academy of Agricultural Research and Management (NAARM) for catering quality research and education in agriculture.

\section{National Institute of Agricultural Extension Management (MANAGE)}

MANAGE was established in 1987, as the National Centre for Management of Agricultural Extension at Hyderabad (Andhra Pradesh), by the MoA, Government of India as an autonomous institute, from which its acronym 'MANAGE' is derived. In recognition of its importance and expansion of activities all over the country, its status was elevated to that of a National Institute in 1992 and re-christened to its present name i.e., National Institute of Agricultural Extension Management. MANAGE is the Indian response to challenges of agricultural extension in a rapidly growing and diverse agriculture sector. The policies of liberalization and globalization of the economy and the level of agricultural technology becoming more sophisticated and complex, called for major initiatives towards reorientation and modernization of the agricultural extension system. Effective ways of managing the extension system needed to be evolved and extension organizations enabled to transform the existing set up through 
professional guidance and training of critical manpower. MANAGE is the response to this imperative need.

The mandate of MANAGE vests the institute with the responsibility to work in the following directions:

- Developing linkages between prominent state, regional, national and international institutions concerned with agricultural extension management

- Gaining insights into agricultural extension management systems and policies

- Forging collaborative linkages with national and international institutions for sharing faculty resource

- Developing and promoting application of modern management tools for improving the effectiveness of agricultural extension organizations

- Organizing need based training for senior and middle level agricultural extension functionaries

- Conducting problem oriented studies on agricultural extension management

- Serving as an international documentation center for collecting, storing, processing and disseminating information on subjects related to agricultural management

\section{STRENGTH, WEAKNESS, OPPORTUNITY AND THREAT (SWOT) ANALYSIS OF THE PUBLIC AGRICULTURAL EXTENSION}

\section{Strengths of the current public extension systems}

India is in process of transforming its agricultural extension and technology transfer systems to become more demand-driven and responsive to farmers needs. There is need to develop skill and knowledge on scientific agriculture. Its wide extension system could be visualized through these facts:

- India has second largest extension system in the world in terms of professional and technical staff. More than 90,000 technical personnel constitute its extension system (Brewer, 2000). Hence, needs to utilize these large human resources for the effective transfer of technology process.

- 100 million farm families are supported by the large agricultural extension services, which is financed by state governments. Since, independence it has used different extension approaches with mixed results supported by over 90,000 staff members (Swanson and Mathur, 2003).

\section{Weaknesses and Constraints that are being or need to be addressed}

Existing weaknesses/constraints in Indian agricultural extension system are mentioned as: 
- The problems and constraints of extension system as identified by Singh et al., (2006) are: (i) Top-down approach (ii) Being commodities and supply-driven specific (iii) Declining farm income (iv) Lack of farming system approach (v) Accountable to government than farmers (vi) Weakening research-extension linkages, and (vii) Little focus on empowering farmers.

- Swanson and Mathur (2003) reviewed agricultural extension system constraints as; (i) Multiplicity of public extension systems (ii) Narrow focus of agricultural extension system (iii) Co-mingling of government schemes and extension activities (iv) Lack of farmers involvement in extension program planning (v) Supply rather than market-driven extension (vi) Lack of transparency and accountability (vii) Inadequate technical capacity (viii) Lack of local capacity to validate and refine technologies (ix) Lack of emphasis on farmers training (x) Weak research-extension linkage (xi) Weak public sector linkages with private sector firms (xii) Inadequate communication capacity (xiii) Inadequate operating resources and financial sustainability.

- Since T \& V system ended, there has been little donor support for extension, and reliance almost solely on state government funding. Extension system of 1990s has been described as weak, ineffective and inefficient (Raabe, 2008). Extension services are characterized by biases that result in tending to neglect poor farmers, particularly women. There has been a wide range of chronic problems in public provision of extension services to poor, particularly in marginal and remote areas.

- High staff vacancy rates, low social status, low rank in the administrative system, lack of operational funds for effective field work and high turnover were reported by Birner and Anderson (2007).

- Major constraints emphasized in $11^{\text {th }}$ FYP recommendations were: (i) Lack of convergence in operationalization of extension reforms (ii) Lack of provision for dedicated manpower at various levels (iii) Inadequacy of funds (iv) Lack of infrastructural support below district level, and (v) Inadequate support for promotion of farmers organizations and their federation.

\section{Opportunities for Strengthening Agricultural Extension with a Farmer Focus}

Public sector extension in both developed and developing countries is undergoing major reforms. Agricultural extension continues to be in transition as governments and international agencies are advancing structural, financial and managerial reforms to improve the pluralistic extension system. Decentralization, pluralism, cost sharing, cost recovery, participation of stakeholders are some of the elements in extension's current transition. Views on extension have changed from an agency of technology dissemination with emphasis on agricultural production to helping farmers organize themselves, linking 
of farmers to markets (Swanson,2006) and providing environmental and health information services (World Bank,2008). The recent reform-oriented initiatives have been directed towards creating a demand-driven, broad-based and holistic agricultural extension system (India, Planning Commission, 2005). This has involved the design and introduction of a multitude of integrated measures that - on the demand side-enable service users to voice their needs and hold service providers accountable, and-on the supply side-influences the capacity of service providers to respond to the needs of the extension service users (i.e., the farmers).

\section{Development of the Agricultural Technology Management Agency (ATMA)}

The evolution of formal agricultural extension system in India is evident from Singh et al. (2012). India's agricultural extension system is at a pivotal point in its evolution. The evidence suggests that investments in agricultural research and extension have served the country well, particularly in achieving food self-sufficiency.

In mid-1990s, the Govt. of India and the World Bank began exploring new approaches to extension that would address the existing problems and constraints resulting in new decentralized extension approach, which would focus more on diversification and increasing farm income and rural employment. The central institutional innovation that emerged to address these system problems was Agricultural Technology Management Agency (ATMA) model that was introduced at the district level by MANAGE to:

- Integrate extension programs across the line departments and the KVKs (i.e. more of a farming systems approach)

○ Link research and extension activities within each district, and

- Decentralized decision making through "bottom-up" planning procedures that would directly involve farmers and the private sector in planning and implementing extension programs at the block and district level.

The model was pilot-tested through Innovations for Technology Dissemination (ITD) component of a World Bank funded, National Agriculture Technology Project (NATP) that became effective in 1998 and concluded in June 2005 (World Bank, 2005).

\section{The ATMA Model}

The ATMA is an autonomous organization registered by MANAGE under the "Societies Registration Act of 1860" that has considerable operational flexibility. For example, it can receive and dispense government funds, enter into contracts, maintain revolving funds, collect fees and charge for services. In addition, it operates under the direction and guidance of a Governing Board (GB) that determines program priorities and assesses program impacts. The head of each ATMA is known as the Project Director (PD) under 
the NATP, reports directly to GB. The PD serves as chair of the ATMA Management Committee (AMC), which includes the heads of all line departments and the heads of research organizations within the district, including the Zonal Research Station (ZRS) and KVK. Consequently, the PD helps coordinate and integrate all agricultural research and extension activities carried out within the district. The organizational structure of the ATMA model is shown in Figure-2.3.

\section{Achievements and Impacts}

The implementation of the ITD component of NATP was monitored and evaluated by an independent agency; the Indian Institute of Management (IIM), Lucknow (IIM, 2004a and 2004b). The resulting monitoring and evaluation reports revealed that these institutional and operational reforms had been largely achieved. In addition, IIM, Lucknow documented the following project impacts:

- More than 10,800 crop or product-based FIGs had been organized at village level, with 85 Farmer Associations (FAs) or FFs being organized at the block and district levels.

Figure-2.3 Organizational Structure of the ATMA Model

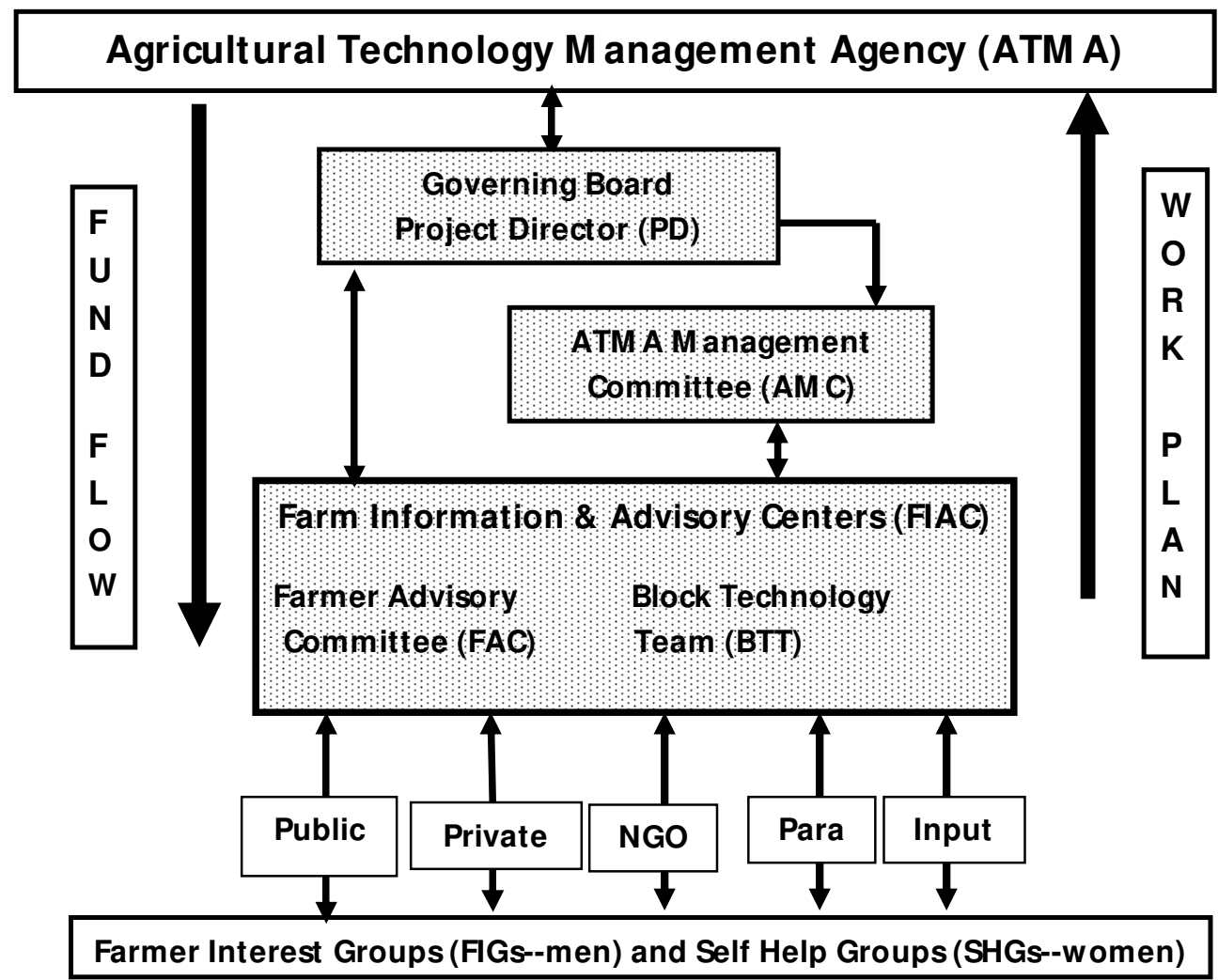


Source: Singh et.al. (2006); Singh et al. (2012)

(http://dx.doi.org/10.2139/ssrn.2168642)

- Approximately 700,000 farmers, including over 100,000 women farmers, directly benefited from these new extension programs through a combination of exposure visits, farmer training courses, on-farm trials, demonstrations and so forth.

- More than 250 farmer-led, successful innovations had been implemented and documented within the ATMA districts.

- Many ATMAs, such as in Maharashtra, developed strong partnerships with private sector firms, ranging from poultry marketing; organic farming; the production, processing and marketing of medicinal \& aromatic crops and export commodities (basmati rice, baby corn, snow peas, etc.); to jointly operating Information Technology (IT) kiosks in collaboration with block-level FIACs.

- ATMA programs have contributed directly to increase rural employment through agricultural diversification, such as the production, processing and marketing of high-value, labor-intensive crop and livestock products, such as vegetables, mushrooms, vermi-composting, floriculture, medicinal plants, fisheries, poultry, dairy and beekeeping.

- Finally, ATMAs have promoted eco-friendly, sustainable agricultural technologies, such as Integrated Pest Management (IPM); Integrated Nutrient Management (INM); organic farming; and the use of water conservation practices, including well recharging, converting from water-intensive crops, such as paddy and wheat, to water extensive crops, such as vegetables, floriculture, maize, oilseeds and pulses. Also, all ATMAs have promoted the use of microirrigation systems.

In addition to these institutional and technological innovations, IIM, Lucknow empirically documented the following impacts of the ATMA approach on the cropping systems and farm income in the 28 project districts during the four year period from 1999-2003:

- Horticultural cropping area increased from 12 to $16 \%$

- Oilseed crop area increased from 3 to $11 \%$

- Herbs, medicinal and aromatic crop area increased from 1 to $5 \%$

- Area planted to cereals declined from 55 to $47 \%$, but yield increased $14 \%$ resulting in no loss in total food crop production.

- Average farm income in project districts increased $24 \%$, in contrast with only $5 \%$ in non-project districts (Tyagi and Verma, 2004).

Encouraged by the success of Pilot Testing of the ATMA Model in 28 districts, the Planning Commission, Govt. of India constituted a working group on Agricultural 
Extension for formulation $\mathrm{XI}^{\text {th }}$ FYP approach (2007-11) with Shri J.N.L. Srivastava as its Chairman; the working group critically reviewed the existing approaches, strategies and on-going schemes and submitted their recommendations on the agricultural extension approaches for $\mathrm{XI}^{\text {th }}$ FYP (GOI, 2007). The centrally sponsored scheme, "Support to State Extension Programme for Extension Reforms" based on ATMA model is an important initiative for revitalization of extension system in the states. The scheme aimed at promoting decentralized, market driven and farmer-led extension system through an innovative institutional arrangement for technology dissemination through ATMA. This institution is an apex body for coordination and management of agricultural extension system at the district level. At the block level, the Block Technology Team (BTT) - a team of line department representatives posted in the block and Block Farmer Advisory Committees (BFAC) - a group exclusively of farmers in the block that are jointly responsible for operationalization of schemes' activities. Extension activities under the schemes are also promoted in Public-Private Partnership (PPP) mode with involvement of both the governmental and non-governmental agencies, including NGOs, Panchayati Raj Institutions (PRIs), Farmers Organizations (FOs), Para Extension workers, agripreneurs, cooperatives, input suppliers and corporate sectors (Swanson et al.; 2006; Singh et al. 2011; DAC, India, 2011-12; Singh et. al. 2012).

There are many success stories in Indian Context, however small farmers produce and market medicinal and aromatic crops are the important success story from Patna District, Bihar, India. One example of the types of procedures that extension could follow in moving to a more market-driven extension system is outlined in Figure-2.4 below.

Singh et al. (2009) assessed the impact of ATMA model in Bihar's context. During the NATP period, ATMAs have been able to generate some financial resources and develop infrastructure to facilitate trainings. Study revealed that scientists have become more responsive to the needs of farmers and focused need based research to meet locationspecific requirement of different farmers. Need-based training and exposure visits to farmers and farmer-led extension have played a very effective role for technology dissemination. There has been considerable improvement in adoption of new technologies and farm practices by all categories of farmers. Technological interventions made by NATP could substantially increase the income of all sections of farmers. It is also noted that NATP was not started in all districts at a time, hence, all districts could not get similar results. Pilot testing of this experiment shows quite encouraging results. The indigenously developed concept of innovative transfer of technology in an integrated manner can be adopted as an integral part of national policy.

Singh et al. (2011) found that decentralizing a large, complex national extension system is not easy, but Government of India appears to be moving toward this long-term goal. Although ATMA model has been successful in addressing many of extension problems 
and has shown exceptional impacts during NATP phase, seems going as the Training \& Visit $(T \& V)$ way. It is therefore, imperative that in a country like India, which has a vast territory and extremely diverse socio-economic and agro-climatic situations, ATMA model should be introduced and implemented with utter caution. ATMA centers should be empowered with sufficient administrative, financial and implementation flexibilities to address basic problems in their operational jurisdiction.

\section{Figure 2.4 Steps in Developing Market-Driven Extension System}

Step 1: ATM A Organizes PRA and then the AM C develops SREP for the District; in the process, Farmer Interest Groups (FIGs) are formed, including men and women farmers

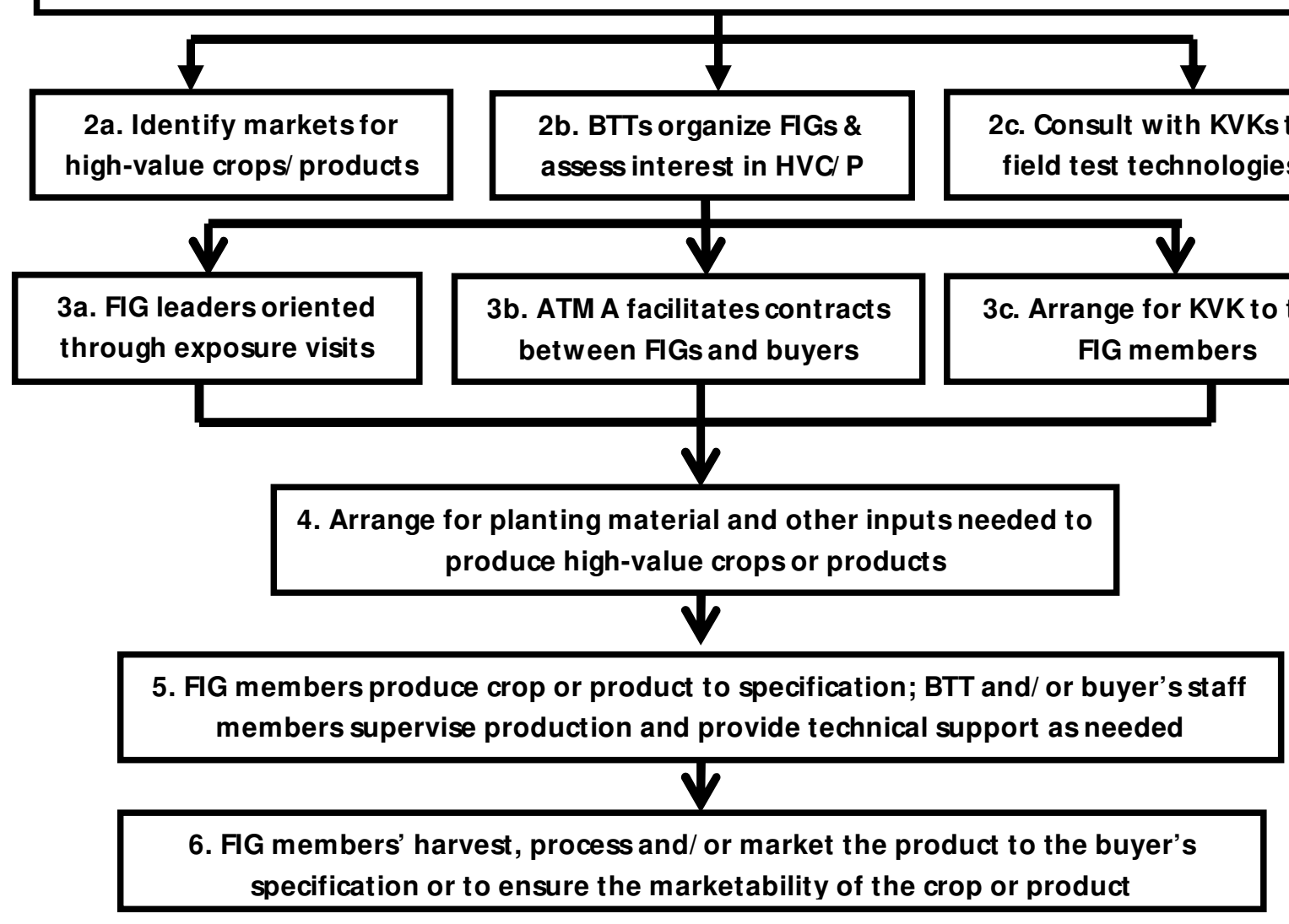

Source: Singh et al., 2006; Swanson, 2008; http://www.fao.org/nr/ext/extn_en.htm).

As of now, ATMAs had been established in 604 districts. Gender concerns are being mainstreamed by mandating that $30 \%$ of resources on programmes and activities are allocated for women farmers and extension functionaries. Since inception, out of a total of 10.19 Crore farmer beneficiaries, 25.80 lakh women farmers (25.34\%) have participated in various extension activities under the scheme (Economic Survey, Govt. of India, 2009-10). 
The scheme has been modified and strengthened during 2010-11 (Figure-2.5) to provide manpower, infrastructure and enhanced active support as enunciated below (http:www.agricoop.nic.in):

i) Provision of specialist and functionary support at different levels viz. State Coordinator and faculty and supporting staff for State Agriculture Management and Extension Training Institutes (SAMETI) at state level, PD, Deputy PDs, and supporting staff at District level and Block Technology Manager (BTM) and Subject Matter Specialists (SMS) at Block level;

ii) Innovative support through a 'Farmer Friend' at village level @1 farmer friend per two village;

iii) Revision in ATMA Cafeteria (i.e., list of extension related activities to choose from) which now includes some additional activities and also provides for enhanced unit costs for some of activities.

iv) Farmers Advisory Committees (FAC) at the Block level, comprising of a group of FIGs and SHGs to advise and provide inputs to administrative bodies at the district level;

v) Support to SAMETIs for creating essential infrastructure; and

vi) Delegation of powers to State Level Sanctioning Committee (SLSC) set up under Rashtriya Krishi Vikash Yojana (RKVY), to approve the State Extension Work Plan (SEWP) prepared under the Extension Reforms Scheme.

Figure-2.5 Revised organizational structure of ATMA scheme 


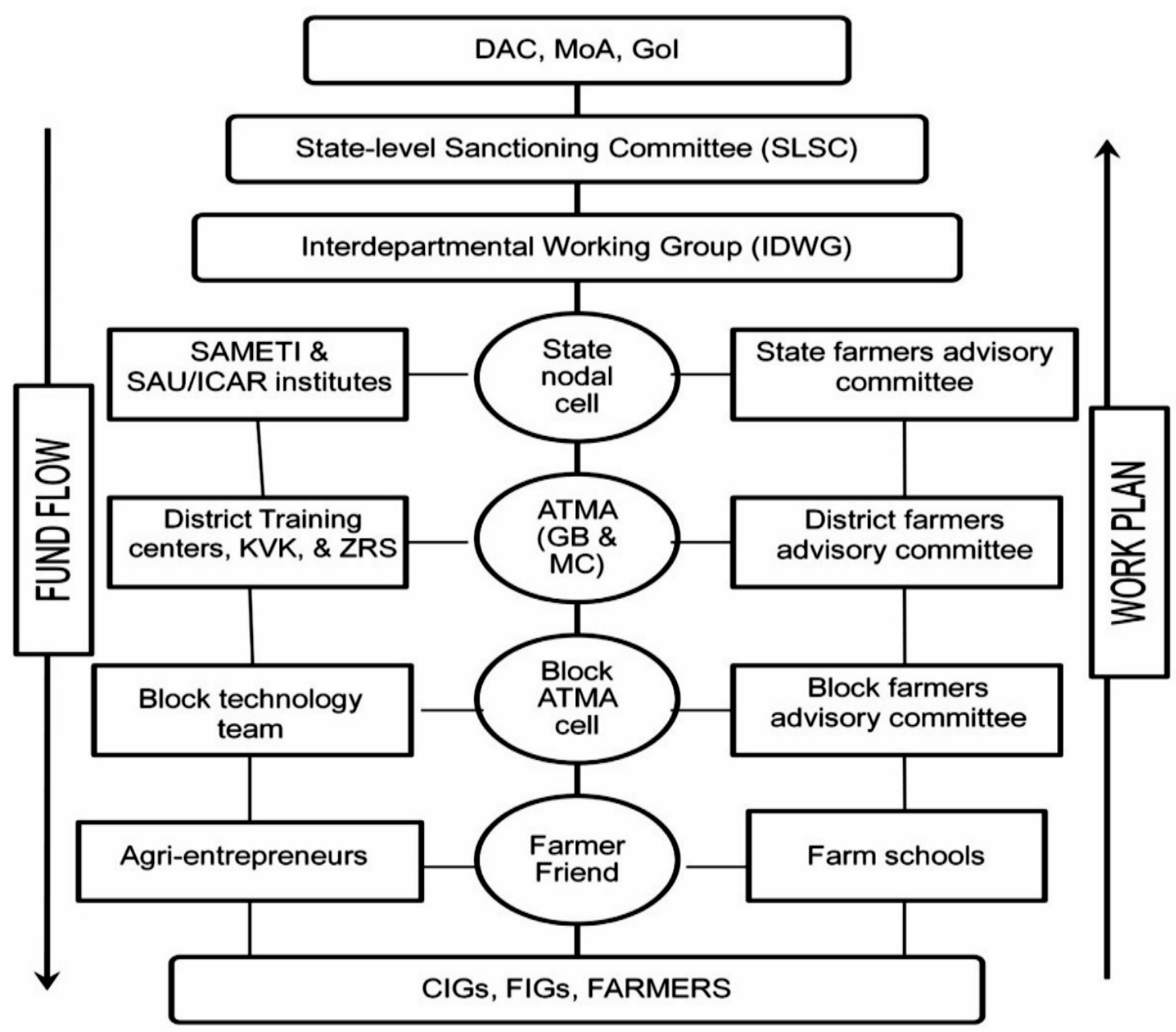

Source: http://agricoop.nic.in/Atmasei21711.pdf

The ATMA model is having a very positive and prompt response from the states with regards to the modifications carried out in the schemes. Consequently, the process of recruitment of manpower began in 22 states with 6937 positions filled up in these states during 2010-11. Further, innovative mechanism of 'Farmers Friend' has begun in 11 states with identification of 27,829 farmer friends. Integration of research and extension systems and convergence of extension activities at various levels have been the important pillars of the schemes. Recent implementation status, progress and physical performances are given below (India, DAC, 2011-12).

First, institutional arrangements viz. Inter Departmental Working Group (IDWG) are now in 28 States and 3 UTs, with the ATMA Core Committees-Governing Board (GB) and the ATMA Managing Committees in 604 Districts; Block Technology Teams (BTT) in 4463 Blocks \& Block Farmer Advisory Committees (BFACs) reconstituted in 3317 Blocks; and FACs have been constituted at the District (215) and State Levels (8). Second, SEWP are now in 28 States/UTs which have been prepared and approved based on District Agriculture Action Plans of 582 ATMA districts with an amount of Rs. 
277.35 Crores being released to these states up to December 2011. The implementation of this scheme and total release since the inception of the scheme in 2005-06 to December 2011 has been to the tune of Rs. 1137.20 crores.

\section{Physical performance}

Physical performance of the scheme since its inception in 2005-06 (April 2005 to December 2011) is as:

o Over 16,975,357 farmers including 4,230,140 farm women (24.92\%) have participated in farmer oriented activities such as exposure visits, trainings, demonstrations and kisan melas ${ }^{4}$.

- Over 89,292 Commodity Interest Groups (CIGs), Farmer Interest Groups (FIGs) and Self-Help Groups (SHGs; women farmers) have so far been mobilized under the scheme.

- Over 32,399 Farm Schools have been organized on the fields of outstanding farmers.

\section{Extension System and Demand-side Reforms}

Demand-side reforms include empowerment of rural population by means of political decentralization, participatory planning and implementation through adoption of farmer field schools and farming system approach, and affirmative action. In technology development and technology dissemination, participatory planning and implementation appear to be the most prominent modes of empowerment.

\section{Demand-side Governance Structures}

On demand sector, governance mechanisms highlight principles of participatory planning and implementation. Participatory approaches are considered to be useful instruments for increasing the productive efficiency of agricultural and rural sector by establishing a decentralized, bottom-up, demand-driven, and financially sustainable technology development and dissemination system. As per Uttar Pradesh Diversified Agricultural Support Project (UP-DASP) initiative (technology development), demand-side reforms were driven by scope and dimension of supply-side initiatives. The supply-side reforms promoted technology development as an instrument to increase use of agricultural knowledge and to make new technologies more adaptable and appropriate to farming conditions. Demand-side governance reforms in technology development were mainly

${ }^{4}$ Farmer's Fair 
targeted toward location-specific agriculture, livestock, sericulture, and horticulture. To overcome communication barriers between different agents, UP-DASP encouraged KVKs and extension agencies of the line departments to conduct on-farm research, validation, and demonstration activities. Furthermore, UP-DASP took measures to encourage participation of farmers in development of technology through farmers' organizations, farmers' SHGs, commodity groups, and producers' associations. The group approach will benefit underlying interest groups if it results in technology recommendations that meet conditions of a narrowly defined production environment (Alex et al., 2002) or promotes more efficient and cost-effective utilization of resources from economies of scale and scope.

Under NATP initiative, program promoted technology development via sponsored research on production systems, crosscutting research, strategic research, and competitive grants research. The local priority research themes controlled for local conditions that were identified by using integrated participatory planning approaches, such as participatory rural appraisal schemes at Zonal level. In contrast, national priority research themes reflected accumulated experience of technical specialists for production systems research (scientific advisory panels) and for other modes of research (research program committees), rather than the experience of farmers as end-users of technology developments. Turning to technology dissemination, the UP-DASP scheme emphasized demand-driven approaches to stimulate the participation of farming communities in the identification of problem areas, in decision making, and in the implementation of proposed interventions. Identical to reforms in technology development system, reforms in technology dissemination system asked farmers to articulate their demands through farmers' organizations, SHGs, commodity groups, and producer associations. The driving forces behind mobilization of farmers were NGOs, which supported establishment and promotion of FIGs in collaboration with front line (district, block, and village) extension workers of line departments and KVKs. NGOs and front-line extension workers received training in financial management, group dynamics, group management, participatory concepts, and leadership skills, among others.

While the technology development component of NATP initiative contained comparatively weak provisions for participatory action, technology dissemination was clearly demand driven and bottom-up. Extension accordingly involved participatory implementation processes at lower tiers of the government (Reddy and Swanson, 2006; Singh and Swanson, 2006). The demand-side of the technology dissemination system was predominantly defined at the block and village levels through the institutional and operational setup of ATMA. Under this agency, programs at the block level were implemented through a FIAC, which was operated by a FAC. The FAC hosted all key stakeholders and farmer representatives. 
The main task of these institutions was to stimulate the foundation of farmers' groups on the basis of a specific commodity or a general purpose at the block and village level. The crucial objective behind the formation of farmers' organizations, commodity-oriented FIGs, farmers' cooperatives, SHGs, or women's interest groups was to make farmers and their organizations fully responsible for the technology system. In addition to the FAC, NGOs supported the mobilization of farmers through voluntary informal interest groups. FIGs are also formed to benefit from possible gains in operational efficiency, possible reductions in the cost of cultivation through the collective purchase of inputs and services, and the realization of scope economies.

\section{Strengthening Human Resource Development}

Capacity building on the demand side improves the ability of farmers to demand good governance and to hold public officials accountable. For being effective, farmers require information on responsibilities of service providers and on enforcement mechanisms. In addition, the success of demand-side initiatives also depends on the capacity of farmers to identify and communicate technology problems and to implement their solutions. Considering DASP and NATP initiatives, human capital development of farmers at the block and village levels mainly concerned the effective and efficient use of agricultural input variables i.e., seed and fertilizer and other technologies. The DASP initiative addressed human capital insufficiencies of farmers by organizing extensive training programs and demonstrations on the main extension themes of IPM, new varieties and management practices for horticultural crops, animal health, breed conservation, and clean milk production. These activities were provided by line departments and KVKs through the ATMA model.

Like UP-DASP and NATP promoted public initiatives toward more intensive training in all project districts of the country through KVKs, ZRSs, and ATICs. The activities included training of farmers, dissemination of research findings, and supply of research products on a cost recovery basis. The ability of public-sector training institutions to adequately meet their envisioned purposes is hampered by (i) tight fiscal budgets and cutback in available financial resources (ii) large number of increasingly diversified farmers, and (iii) need to provide training units that reflect up-to-date information (Chandre Gowda and Samanta, 2002). The public-sector training activities were therefore supported by private and third-sector organizations. Third-sector institutions taught farmers to form and manage voluntary informal farmers' organizations and thus created

platforms for the effective dissemination of technology innovations. Private-sector organizations provided training and technical recommendations on efficient and adequate use of inputs to farmers and disseminated farmer-driven and farmer-accountable 
technologies at district level. In providing information on use of inputs and on scientific management of crops and cultivation practices, among others, private sector reinforced trends of diversification and thus intensified agricultural activities.

\section{Positive Aspects of UP-DASP and NATP Initiatives}

Favorable action includes explicit measures such as training and/or reservation of seats in elected bodies of local government for women and disadvantaged groups. It describes steps that are taken to empower rural people to demand agricultural and rural services they need, and to make service provision and financing accountable to elected bodies of local government (Birner and Palaniswamy, 2006). Both UP-DASP and NATP initiatives contained provisions for empowerment and mobilization of women and took actions to promote participation of women in planning and implementation process of agricultural research and extension. Both programs promoted formation of farmer and SHGs for women and required that $30 \%$ of farmer representatives on ATMA Governing Board and block level FACs are women (World Bank 2005; Reddy and Swanson, 2006). The NATP program imposed additional requirement that at least $30 \%$ of budget for extension and research programs would be allocated to women farmers and women extension functionaries. Gender empowerment was a key priority for many projects aimed at strengthening the position in the society of women with small and marginal farms and increasing their productivity and hence income by training them in application of lowcost technologies like seed selection and treatment, post-harvest storage etc.

Furthermore in gender-focused projects, reform efforts were also directed toward improving livelihood of disadvantaged tribal groups. The Andhra Pradesh Tribal Development Project was implemented during 1991-98 in 2,077 villages in four districts that were home to four contiguous and 63,370 tribal households. With annual income levels in the range of Rs 2,660 to Rs.3,770 at the start of the program, the tribal groups faced severe food insecurity. By improving income, food security, and living conditions of tribal groups, International Fund for Agricultural Development (IFAD) initiative institutionalized participatory actions of tribal farmers and women within the framework of SHGs, cluster-level associations of SHGs, and village development committees, agricultural consultants, village tribal development associations, and so-called community coordination teams.

Village tribal development associations were nodal institutions designed to prioritize extension needs and to deliver development programs to community. Community coordination teams were groups of young professionals who were supposed to assist village extension workers in social mobilization, awareness building, technology dissemination, and identification of needs, around which development interventions 
could be built. SHGs were also seen as a medium of technology dissemination and as a source of information regarding irrigation, horticulture development, soil conservation, as well as marketing, savings and credit activities (IFAD, 2001).

\section{Support of Information and Communication Technologies (ICTs)}

There has been considerable growth in connectivity, content, and capacity of ICT sectors of South Asia during the last decade (Pradhan and Liyanage, 2010). However, the South Asian region still lags behind developed countries in the ICT development Index published in 2010 by International Telecommunication Union (ITU) —a United Nations Agency for ICT. Of 159 countries in International Development Index (IDI), Sri Lanka ranks 105, India is 117, Bhutan 123, Pakistan 128, Bangladesh 137 and Nepal 142 (ITU, 2010). The support of ICTs can be best visualized by the DAC Report 2011-12 (http://www.agricoop.nic.in). Mass media support to agricultural extension scheme is focusing on use of Doordarshan (DD) and All India Radio (AIR). Existing infrastructure for providing agriculture related information and knowledge to the farming community through national channel, 18 Regional Kendras and 180 High/Low Power Transmitters (HLPT) of DD are telecasting agricultural programmes for 30 minutes, 5-6 days a week. Programme of Regional Kendras are a few narrow casting centres are being repeated the next day on respective Regional Satellite Channels. Similarly, 96 FM stations of AIR are being utilized to broadcast 30 minutes of programme for farmers 6 days a week.

For telecasting success stories, innovations and for popularizations of front line technologies and farming practices through the Saturday slot of DD's national channels, DAC is producing films which would consciously project interalia positive aspects in agriculture in India. The stories cover various aspects like zero tillage, water conservation, farm school etc. For increasing viewership and provide enhanced content to the farmers, the transmission timings of "Krishi Darshan" programme telecast from 25 out of 27 Narrowing Kendras, where Regional Kendras ${ }^{5}$ also functioning so that the farmers can view the programmes telecast by both Regional and NC Kendras, thereby benefitting farmers located in the range of 125 High Power/Low Power transmitters (HPT/LPT) who are now able to view one hour agricultural programmes against the earlier half hour programme.

The Free Commercial Time (FCT) available under Krishi Darshan and Kisanvani programme is being utilized for dissemination of advisories on Rabi/Kharif, Kisan Credit Card (KCC), package of practices available to the farmers under various schemes of DAC, Minimum Support Price (MSP), contingency plan developed by state governance on emergent issues like Drought, Flood etc. KCC scheme was launched on $21^{\text {st }}$ January

\footnotetext{
${ }^{5}$ Kendra $=$ Centre
} 
2004 to provide agricultural information to the farming community through toll free telephone lines. A country wide common eleven digit number ' $\mathbf{1 8 0 0 - 8 0 0 - 1 5 5 1}$ ' has been allocated for KCC. The replies to the queries of the farming community are being given in 22 local languages. Calls are attended on all 7 days of the week. Since inception of the scheme till $30^{\text {th }}$ November, 2011 over 73.79 lakh calls have been received.

Community Radio Stations (CRSs) would make a major contribution to agricultural extension by utilizing the reach of radio transmitter and disseminating information and knowledge, produced locally having relevance for a specific area. Till date 68 proposals have been received from KVKs/Private Institutions for funding of CRSs under ATMA, 43 were found in order for funding and have been submitted to Ministry of Information \& Broadcasting for issue of licenses. Out of these, Letter of Intent (LOI) i.e. permission of issue of license has been issued to $18 \mathrm{KVK} /$ Private Institutions, 6 proposals have been rejected by Ministry of Information \& Broadcasting, 11 proposals are under process and 8 CRSs were in operation up to November, 2011.

\section{Setting Up of Community Radio Stations (CRSs)}

Community radio is a powerful tool for the poor, not-for-profit companies meant to serve the society. They have enormous benefits as an information and communication tool and are being used to great effect all over the country. One of the milestones of the Community Radio Guidelines of 2006 was the creation of a distinct three tiered radio policy-public, private and community-based on the promise of inclusiveness and equity. The current policy on Community Radio in India announced in 2006 was an amendment of the earlier policy, and had gone beyond educational institutions to include Community Based Organisations (CBOs), SAUs, and KVKs under its ambit. Now this policy has been in operation for six years, there are enough accumulated experiences and evidence to suggest that certain aspects of policy guidelines need to be reconsidered.

To support the state extension programmes, there is a provision of setting up these CRSs. In this, funding to private institutions along with Government and Quasi-government organizations for setting up CRSs can be considered. CBOs, agencies/NGOs registered under Societies Registration Act, 1860 or any other such Act and recognized by Central Government/State Government and serving in agriculture and allied areas including SAUs and KVKs are eligible for funding. Registration at the time of application should be at least three years old. The willing organizations should have basic infrastructure and facilities in form of a room of about 400 sq. feet/electricity/necessary manpower to run and operate the CRSs. Presently, 158 Community FM Radio stations are functioning in India. Tamil Nadu state has maximum of 26 CRSs followed by Uttar Pradesh and Maharashtra (Fig-2.6).

\section{Figure-2.6 Community Radio Stations across Indian states.}




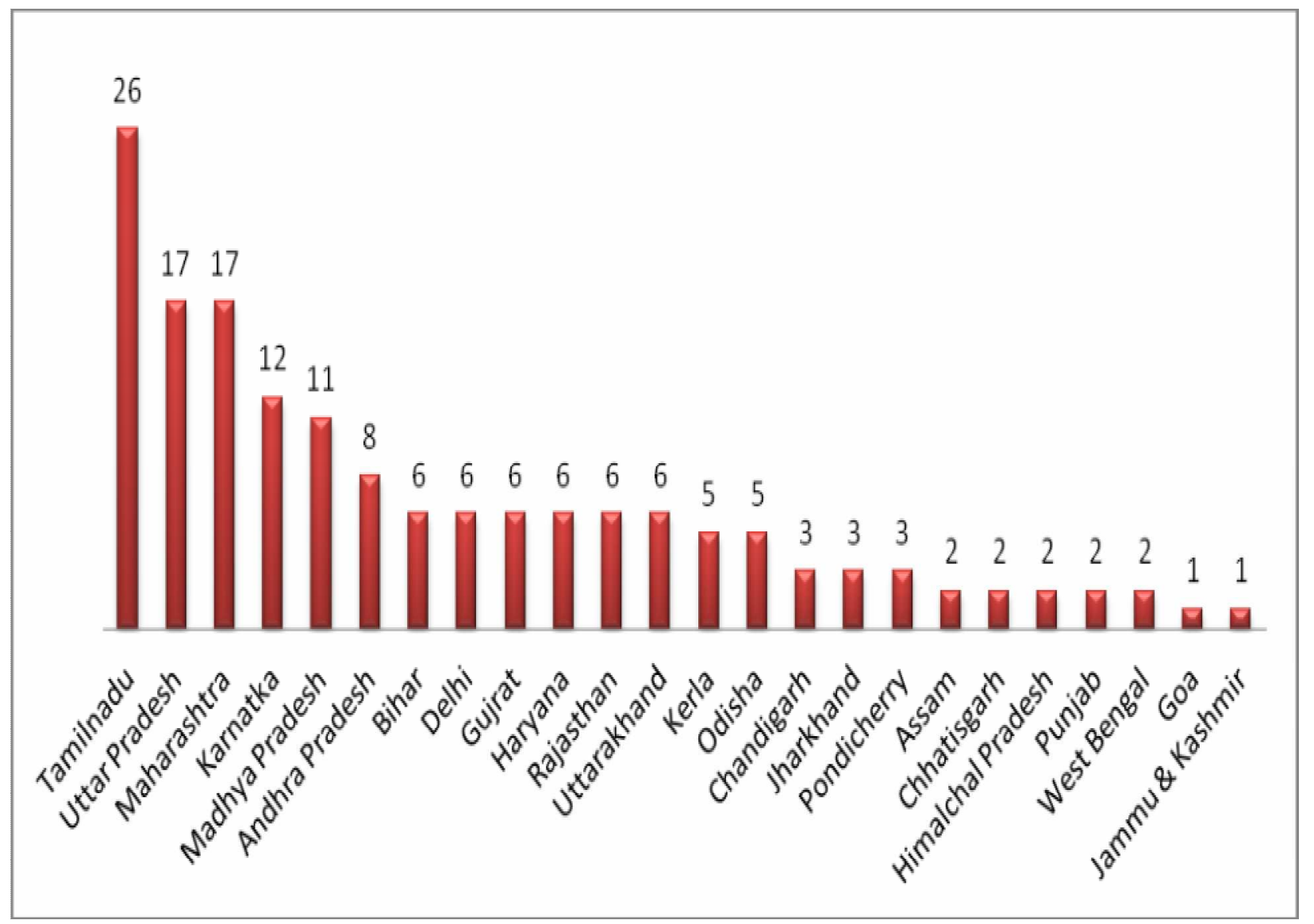

Source: Reports of Ministry of Information \& Broadcasting. http://qsl.net/vu2jos/fm/cr.htm

ATMA Management Committee (AMC) of district concerned may select suitable proposal/s; recommend them to the Nodal Officer/Commissioner of Agriculture of concerned State for onward transmission to DAC through the competent authority. The Project Director (PD), ATMA would regularly review the performance of CRSs along with other activities with BTMs. In addition, ATMA Governing Board (GB) would review performance in detail with regard to content creation, involvement of local community, suitability to local conditions, release/ utilization of funds for/by CRS and convergence \& synergy with SAU/KVKs.

\section{Human AND FinanCial Resources}

Most funds for agricultural research in India are allocated through block grants, but funding through competitive grants is now gaining acceptance, especially for operating and equipment costs. For $11^{\text {th }}$ FYP (2007-12), Planning Commission had communicated a total outlay of Rs. 12023 Crore (INR 120230 Million). During 2008-09, against projected demand of Rs. 2646.78 Crore, allocation was Rs. 1760 Crore. During 2009- 
2010, against projected demand of Rs. 4000 Crore, allocation was retained at same level of 2008-09 i.e. Rs.1760 Crore. Most public funding to agricultural Research and Extension takes form of block grants to ICAR and the SAUs, with allocations determined by FYPs. The approved outlays are basis for each institute's funding during the plan period, and funds received are demarcated as "plan funds." On-going activities of previous plan are financed under "non-plan funding" which primarily pays salaries and other fixed costs. A similar procedure is followed for state funding, except that state allocations are first determined by Planning Commission as part of total plan allocations to states. Both plan and non-plan expenditures on $\mathrm{R} \& \mathrm{E}$ are then approved by respective state governments.

\section{HUMAN RESOURCES IN THE INDIAN RESEARCH SYSTEM}

India is one of the largest and most complex agricultural research systems in the world. Public-sector research institutes form the backbone of agricultural research system. In India, majority of agricultural scientists work for government agencies. Most of them are engaged with the triple function of education, research and extension. Since precise and consistent estimates of scientific staff in ICAR/SAU system over time are not available, rough estimations made by Pal and Singh (1997), and Ramaswamy and Selvraj (2007) approximate the number of scientists working in the ICAR/SAU system during the late 1980s to be 4,189 scientists in ICAR and 14,851 scientists in SAUs, giving a total scientific strength of 19,040. Number of scientists remained steady in ICAR during 1990s (4,092 in 1998) and increased marginally to 4609 in 2005-2006 (DARE/ICAR, 2006). However, numbers decreased significantly in SAUs (17,678 in 1992). It has declined by $24 \%$ in last decade (Ramaswamy and Selvraj, 2007) because of non-replacement of retiring faculty and restrictions on recruitment.

Adjusting number of scientists by share of research expenditure relative to extension and education (for ICAR) and percent time spent on research (for SAUs), number of full-time scientists in late 1990s was 2,999 in ICAR and 8,132 in SAUs, giving a total of 11,131 full-time researchers in country and making it one of the largest agricultural Research and Development (R\&D) system in the world. This is a substantial increase from an estimated 5,666 full-time researchers in ICAR/SAU system in 1975 and 8,389 in 1985 (Pardey and Roseboom, 1989). However, investment of Rs. 4.20 lakh per scientist in 2001-2002 was decreased from Rs. 4.32 lakh during 1992-1994. Scientists' intensity per 1000 hectares of gross cropped area was 8.34 during 1992-1994 and declined to 5.90 in 2001-2002. In 2005-2006, agricultural scientists of ICAR institutes were supported by a large technical staff (7355), administrative staff (4705) and supporting staff (9067). However, ICAR as well as SAUs are downsizing administrative staff to balance ratio of scientific staff to supporting staff. Ratio of social scientists in ICAR and SAUs was $7.6 \%$ and $11.7 \%$ 
during the year 2001-02. However, women's ratio in ICAR and SAUs was $11.9 \%$ and $11.3 \%$, respectively (Jha and Kumar, 2006). If we evaluate the DOE, at present, sanctioned strength of 365, out of which 226 (61.91\%) posts are filled up (http://vistar.nic.in/organisation/Administrative.asp).

As per $11^{\text {th }}$ FYP recommendations, adequate trained manpower is needed to promote Farmer Field Schools. Required fund provision is made at State Agriculture Management and Extension Training Institutes (SAMETI) to train 40,000 master trainers. SAMETI's will make use of the expertise from SAUs, KVKs, NGOs and private sector to develop master trainers, who in turn promote FFSs. The existing centrally sponsored schemes are mainly supported with inputs, leaving extension aspects to state governments. In most of states, though manpower is available, funds for grounding extension activities are inadequate. Fund earmarked for extension activities under ATMA is only for gap filling mode and per capita availability of extension fund is very low. About 90,000 extension functionaries are now working in various states in different capacities at district and block level in the field of agriculture and allied sectors. Out of these nearly 50,000 functionaries are with requisite qualifications having an experience of 10-15 years.

\section{FINANCIAL RESOURCES IN INDIAN'S RESEARCH AND EXTENSION SYSTEM}

As compared to other alternatives, investment in agricultural research and extension is much more productive in accelerating pace of development. It has been shown empirically that investment in agricultural research and extension is the main source of growth in agricultural total-factor productivity in India, and rates of return are impressive (Kumar and Rosegrant, 1994). The Union Government supports ICAR, which is the apex body of agricultural research, extension and education in the country. In addition to financing the ICAR institutes and research centres, a part of the fund is allotted to SAUs in form of research programs and annual grants (ICAR Budget Book, 2005-2006). SAUs are largely funded by state governments, but they also get regular grants from ICAR.

Mohapatra and Sahoo (2008) studied trend in public funding (central and state governments) of agricultural research and education, shows an increasing trend in the investment. Investment in public research and education reached Rs. 500.30 crore by 1980-1981 from Rs.160.10 Crore in 1960-1961. After 1980-1981 this funding went skyhigh and reached Rs. 2196.98 Crore in 2004-2005, a more than tenfold increase in the last four decades, albeit at only $0.30 \%$ of agricultural Gross Domestic Product (GDP) in recent years. There is a consistent increase in the funding of agricultural research and education. A break-down of total investment by center and state governments shows that investments made by both governments showed an increasing trend except for 1970-1971 
where the center's share in the total investment remained as low as $3.3 \%$. Funding from state accelerated during 1960s and 1970s because of establishment of a large number of SAUs during that period. Central government investment increased consistently thereafter, and during 2004-2005, it surpassed the state government investment.

An important policy gain of recent years is the turnaround in public investment in later years of the $10^{\text {th }} \mathrm{FYP}$, reversing years of decline. Overall capital formation in the sector is now $12 \%$ of agricultural GDP, which is the highest in 25 years. This must have contributed to the recent upturn in growth.

\section{CHALLENGES IN FRONT OF INDIA's EXTENSION SYSTEM}

In current scenario, where a numbers of stakeholders are involving in agricultural extension, hence, opportunity to reach a greater number of farmers is increasing. In this context, private sector is incorporating extension services within existing service provisions and experimenting with ICT. But inherent challenges each sector faces in reaching different farmers means that partnership and coordination between sectors will best serve the interests of farmers. Hence, addressing of current challenges is necessary.

\section{Public Sector Extension System}

- In Indian extension system, information flow within public sector moves linearly, with content focusing on transfer of technology for enhancing agricultural production. A wider definition of agricultural extension, beyond improving crop productivity, has not been embraced. Information flow is supply-driven and not need based or area specific (Raabe, 2008), therefore farmers see the quality of information provided by public extension staff as a major shortcoming (NSSO, 2005).

- There are also insufficient funds for operational costs, training, and capacity development, which limits the activities and continual development of the extension staff (Swanson, 2006). However, it was experienced that there are about 90,000 on the job, which is an adequate number of extension workers for the number of farmers (about 130 million).

- Various line departments at the state and district levels have been criticized for working in isolation, with weak linkages and rare partnerships. The researchextension link has been criticized for not absorbing or using feedback from farmers and extension staff. Extension personnel and farmers are passive actors, and scientists have limited exposure to field realities (Reddy et al., 2006).

- Numerous components of public-sector extension system suffer from duplication of programs, without convergence. While ATMA is pushed as the platform through which the multiple agencies can converge, the implementation difficulties 
are proving great for effective integration, with shortages of both personnel and funds (Working Group on Agricultural Extension, 2007).

\section{Private Sector Extension System}

To diffuse agricultural information directly to farmers, private-sector examples are developing context-specific models and using ICT tools.

- In India, private sector is playing an important task in extension services. The public sector recognizes this, with the policy framework for agricultural extension referring to the need for public extension services not to crowd out private services. Additionally, policy framework for agricultural extension notes that "public extension by itself cannot meet specific needs of various regions and different classes of farmers" (India, DAC, 2000).

○ In the pluralistic extension systems, private sector can provide services related to proprietary goods, while the public sector can provide extension services related to public goods, which tend not to be addressed by private-sector firms (Swanson, 2008).

○ Furthermore, private sector serves a corporate interest, working with individual farmers, so social capital is not built. Moreover, private extension can only work well if farmers are willing and able to pay indirectly through the sale of inputs. Swanson (2008) suggested that private sector could serve the needs of mediumsize and commercial farmers, while the public sector could work in remote areas, which are currently not serviced well. This sort of system would require PublicPrivate Partnerships (PPP) that currently does not exist in India. It would mean changes in the way the public sector views and interacts with the private sector. Relying on the public sector may also be difficult for remote and resource-poor farmers, considering the existing problems and poor reach of the public sector in those areas.

\section{Civil Society (NGO) Extension Systems}

Within information value chains, the capacity of farmers to articulate their needs will influence their ability to obtain information they need. Considering a large number of marginal and small land holdings in India, both the FIGs and SHGs can play important roles in articulating the needs of men and women farmers to knowledge intermediaries. These FIGs/SHGs can operate side by side with either NGOs or the public sector. However, challenges exist in both sectors.

- Public capacity to build FIGs and SHGs is limited, while NGOs, which are not numerous, rely on donor funds and would need public support to develop the technical skills to facilitate groups (Swanson, 2008). 
- Building social capital is critical in overall agricultural development strategies for reducing rural poverty (Swanson, 2006). In a large country like India, through public extension system, meeting of scientists with farmers and visit of farmers to research institutes is a time consuming and difficult task. Both FIGs/SHGs are already emerging as an effective mechanism for both the transfer of technologies and the empowerment of the rural poor (Meena et al., 2003; Meena et al., 2008). Adoption of this approach can reduce the extension cost and workload of extension functionaries.

- For that, ICTs could be useful tools to increase connectivity between the various FIGs/SHGs and different extension approaches. Covering the whole country where diversities and complexities are prevalent in agriculture as well as mentally makeup for converting into social capital (especially of the downtrodden, like landless laborers, smallholders, rural women etc.,) is a herculean task.

- For harnessing the ICTs, there are many challenges prevalent like insufficient infrastructure, sustainability aspect, capacity development etc., which needs to be addressed.

- Capacity building of SHGs/FIGs and promoting development of leadership and management skills are utmost needed so that farmers can demand information they need. It is therefore an important component of agricultural extension approaches.

\section{LESSONS LEARNED}

In the present scenario of changing climate, fragmented and small land holdings, nonjudicious use/limited water availability, indiscriminate application of inputs, increasing fuel costs, lack of efficient market opportunities etc.-farmers want access to timely, reliable, and relevant information which can support the complexity of their farming systems. Presently, Indian agricultural extension has wide mandates and despite the pluralistic extension approaches, its coverage and use of services is limited; particularly in rain-fed regions that are represented by marginal and smallholder farmers'. Hence, there is need to develop "need-based" capacity building of small-scale men and women farmers, as well as gaining access to reliable information in increasing their productivity and profitability for livelihoods improvements.

Local contexts necessitated the innovative extension approaches in India; evolved over time which has expanded beyond the linear transfer-of-technology approach, but this still has shallow roots within the public extension system. However, the Indian public extension system is still a major source of knowledge for the needy men and women farmers and receives significant investment from the central government. ATMA is the 
key component, which proved very useful during the pilot study and is now functioning throughout India.

At the national level, it still carries some of the deficiencies of the public-sector extension system, which has reduced its impact due to limited staff, poor capacity, and weak links to the research system (especially the KVKs), as well as limited reach to farmers. Hence there is need to delink public administration from extension and the need to be more closely linked with the research system, especially the KVKs at the district level, where specific technologies are largely generated.

India's pluralistic extension system includes public sector, private sector and NGOs, all playing different roles; however, these sectors still tend to work in isolation. The difficulties of working with the public sector mean that the private sector has few partnerships with public-sector extension. It should be noted that agri-clinics and agribusiness centres supported by MANAGE-has proved to be a very successful PPP that should be strengthened and encouraged. It can strengthen the link between agripreneurs and agribusiness companies, as input supply is considered to be an important component of many Agriclinics. There must be softness at the local level to facilitate PPP so that complementarities can be achieved to meet the needs of men and women farmers. Nevertheless, the need to inculcate the PPP concept in their culture and attitudes is not common.

Building social capital is critical in overall agricultural development strategies aimed at reducing rural poverty. FIGs/SHGs have already emerged as an effective mechanism of empowerment and development of rural poor. Efficient transfer of technology to the user population is also evident from different studies. It can reduce the extension cost and workload of extension functionaries to a greater extent. Contacting farmers (FIGs/SHGs) is an innovative idea for public extension, while ICTs can increase the connectivity between the various FIGs/SHGs and extension.

India's pluralistic extension system must be capable to tackle the diverse emerging issues in agriculture. This system should also support and deal with the pertinent areas beyond the production aspect, such as processing and value addition, market access, trade, agribusiness management, natural resource management, gender, climate change etc. Within this paradigm of innovation systems, extension agencies can act as innovation intermediaries or innovation brokers, working with many partners to strengthen linkages and provide support for innovations including extension delivery.

In agricultural innovation systems, there are still large gaps between research and extension approaches. Hence, there is need to evaluate the performance and socio- 
economic impacts of research and extension programs. Also, a greater understanding of PPP is also required; including the mechanisms that help encourage partnerships. There is a want for a thorough evaluation of extension approaches in order to identify best

practices and to understand their impact on farming communities in reaching small-scale and marginal farmers.

\section{SUMMARY AND THE WAY FORWARD}

The need for reforming the extension system in India was deliberated extensively in a resolution made by National Development Council (NDC) and National Policy for Farmers in 2007. However, for meeting the challenges of agricultural development, there is still a need to redefine the structure and function of the agricultural extension system.

- The ATMA model has been successful in addressing many extension problems and in showing major impacts during the NATP project. Hence, the ATMA model should be introduced and implemented vigilantly. ATMAs should be empowered with sufficient administrative, financial and implementation flexibilities to address basic problems in their operational jurisdiction between research and extension.

- Public extension system dominates the provision of knowledge and information to farmers. The ATMA model is increasing demand-driven extension and encourages crop diversification across the entire food and agriculture value chain.

- Pluralistic extension service providers are offering diverse kinds of services such as information and service support to farmers like State Government, Central Government agencies, agri-business companies, agripreneurs, input dealers, manufacturing firms, NGOs, and progressive farmers etc. However, there is a duplication and dilution of efforts with multiplicity of extension agents without convergence. It needs coordinated attempt to synergize and converge efforts at district and block levels to improve the performance of stakeholders. It is essential to route all the State and Central Government extension funds and human resources through a single agency (i.e. ATMA), for effective utilization of crucial resources.

- Extension is suffering from lack of human and financial resources; therefore, state governments should provide proper financial support by allocating at least $20 \%$ of their total budget to ATMA, which in turn distributes these funds to the departments of agriculture, animal husbandry, fishery, horticulture, forestry and any departments related to agriculture. Also, the development grant provided by ICAR to agricultural universities and KVKs should be reviewed and adequately enhanced.

- Private sector initiatives, like e-Choupal, and other small-scale models have explored possibilities to provide information on diverse areas from production to 
accessing markets. ICTs could be useful tools to increase connectivity between the various FIGs/SHGs and extension approaches. Multiple ICTs approaches are not properly documented hence the need to concentrate and work with small communities by modern ICTs.

- The role of building social capital has already been proved. Scaling up of FIGs/SHGs and Farmers Associations (FAs) could be an effective mechanism for empowerment and transfer of agricultural technologies. It will also reduce extension cost and the workload of extension functionaries. Hence, enriching the system with social capital is the need of hour.

- A greater understanding of PPP is also required including mechanisms to help encourage partnerships. There is a need to identify and encourage best practices and, thereby, understand their impact on farming communities predominantly in reaching smallholder and marginal farmers.

- The absence or weak Research-Extension-Farmer linkage is the main limiting factor for enhancing output through the effective dissemination of agricultural technologies. It can be best served through efficient linkages among technology generation, dissemination and adoption. Adequate fund allocation to reach large numbers of small and marginal farmers by ATMA is essential. Infrastructure below district level is needed to support the capacity building of farmers. There is also need to strengthen ATMA across the whole country, incorporating key modifications and emerging needs.

\section{References}

Alex, G., W. Zijp, and D. Byerlee (2002). Rural extension and advisory services: New directions. Rural Development Strategy Background Paper No. 9. Agriculture and Rural Development Department. Washington, D.C.: World Bank.

Brewer, F (2000). History of Indian Extension. (http://web3.canr.msu.edu/vanburen/India/histupd.htm.

Birner, R., and N. Palaniswamy (2006).Public administration reform and rural service provision: A comparison of India and China. Manuscript. Washington D.C.: International Food Policy Research Institute.

Birner, R. and Anderson, J. (2007). How to make agricultural extension demand-driven? The case of India's agricultural extension policy. Discussion Paper 00729.Washington D.C., International Food Policy Research Institute. 
Chandre Gowda, M. J., and R. K. Samanta (2002). Dynamics of collaboration in the activities of Krishi Vigyan Kendras. MANAGE Extension Research Review 3 (1): $50-67$.

DARE (2006). Annual Report, New Delhi.

DARE/ICAR (2009-2010). Annual Report, New Delhi. www.icar.org.in/en/node/1107.

Economic Survey, Govt. of India (2009-10). Ministry of Finance, Department of Economic Affairs, Economic Division, Feb., 2010. Oxford University Press, New Delhi.

Farrington, J., Sulaiman, V.R. and Pal, Suresh (1998). Improving the effectiveness of agricultural research and extension in India: An analysis of institutional and socio-economic issues in rainfed areas. Policy Paper 8, National Centre for Agricultural Economics and Policy research, New Delhi.

http://www.icar.org.in/en/agricultural-extension.htm (accessed on 25.11.2012).

http://planningcommission.nic.in/plans/planrel/12appdrft/appraoch_12plan.pdf (accessed on 25.11.2012)

http://qsl.net/vu2jos/fm/cr.htm (accessed on 25.11.2012).

India, Department of Agriculture \& Cooperation (2000). Policy framework for agricultural extension (draft).Extension division, DAC, Ministry of Agriculture, Government of India, New Delhi.

Indian Institute of Management, Lucknow (2004a). Impact Assessment Report, on the Innovations in Technology Dissemination (ITD) Component of the National Agricultural Technology Project, Agriculture Management Centre, 2004.

Indian Institute of Management, Lucknow (2004b). Successful Case Studies, Interventions and Innovations in Technology Dissemination, Agriculture Management Centre, 2004.

International Fund for Agricultural Development (IFAD) (2001). Andhra Pradesh Tribal Development report, Completion evaluation. (Available at http://www.ifad.org/evaluation/public html/eksyst/doc/prj/region/pi/india/andhra. htm) Accessed on June 7, 2007

ITU (2010). Measuring the Information Society 2010. International Telecommunication Union (ITU): Switzerland.

India, DAC Annual Report (2011-12). Department of Agriculture \& Cooperation, Ministry of Agriculture, Government of India. March 2012. http://www.agricoop.nic.in (accessed on 01.12.2012).

ICAR, Annual Reports (Various years 1990 onwards), New Delhi.

ICAR (1996). ICAR Now and Ahead, New Delhi.

ICAR (2005-06). Budget Book, New Delhi. 
Jha, D. and Kumar, S. (2006). Research resource allocation in Indian agriculture. Policy Paper No. 23. Delhi, National Centre for Agricultural Economics and Policy Research.

Kumar, P. and Rosegrant, M. W. (1994).Productivity and sources of growth for rice in India, Economic and Political Weekly, Dec. 31, pp 183-188.

Meena, M. S., Bhagwat, V. R., Jain, R. K. \& Ilyas, S. M. (2003). Self-Help Group: An Effective Instrument for Transfer of Technology. CIPHET Extension Bulletin1.Central Institute of Post-Harvest Engineering \& Technology, Ludhiana, India.

Meena, M. S., Jain, Dilip and Meena, H. R. (2008). Measurement of Attitudes of Rural Women towards Self-Help Groups, The Journal of Agricultural Education and Extension, 14: 3,217-229.

Mishra, S. and B.E. Swanson (2009) Extension's Role in Organizing Producer Groups: a Case Study from Orissa, India, Proceedings of the $25^{\text {th }}$ Annual Conference of the Association for International Agricultural and Extension Education (AIAEE)

Misra, D. C. (1990). New Directions in Extension Training-A Conceptual Framework, Directorate of Extension, Occasional Paper-3, Directorate of Extension, Ministry of Agriculture, New Delhi, India.

Mohapatra, S. and Sahoo, B. K (2008). Agricultural Research and Development in India: Trends, Patterns, Determinant and Policy Implication. Presented at the International Conference on Issues in Public Policy and Sustainable Development held in New Delhi. Available at:

www.ignou.ac.in/schools/soss/FINAL_SOSS_CONFERENCE/full_\%20papers/A 3/Simantini\%20\&\%20B.k.\%20Sahoo-2.pdf

National Institute of Agricultural Extension Management (MANAGE) (2004). Process Change in Agricultural Extension: Experiences under ITD Component of NATP, 2004.

NSSO (National Sample Survey Organization) (2005). Situation assessment survey of farmers: Access to modern technology for farming, 59th round (JanuaryDecember 2003). Report No. 499(59/33/2). New Delhi: Ministry of Statistics and Programme Implementation.

Pardey, P. G., and J. Roseboom (1989). ISNAR agricultural research indicator series. Cambridge, UK: Cambridge University Press.

Planning Commission (2008).XIth Five Year Plan (2007-12). Ministry of Finance, Government of India, New Delhi.

Planning Commission (2010). Mid-term Appraisal XI Plan, Planning Commission for Agriculture, Government of India (Accessed on 05.05.2010). 
Pal, S., and A. Singh. (1997). Agricultural research and extension in India: Institutional structure and investments, Policy Paper-7, New Delhi: National Centre for Agricultural Economics and Policy Research.

Raabe, K. (2008). Reforming the agricultural extension system in India: What do we know about what works where and why? IFPRI Discussion Paper 00775. Washington, D.C.: International Food Policy Research Institute.

Ramasamy, C. and Selvaraj, K. N. (2007). Prioritizing Agricultural Research and Extension, INRM Policy Brief No. 15, Asian Development Bank.

Reddy, M. N., and Swanson, B.E. (2006).Strategy for up-scaling the ATMA model in India. In Proceedings of the Association for International Agricultural and Extension Education(AIAEE) 22nd Annual Conference, Clearwater Beach, Florida, U.S.A.

Report of working group on agriculture research and education for the eleventh for the five year plan (2007-2012). Government of India, Planning Commission. (http://dare.nic.in)

Singh, J.P. (2005). From Self-help Groups to Commodity-based Commodity Associations: The Indian Approach to Mobilizing Rural Women, presentation at the Workshop on Building New Partnerships in the Global Food Chain, Chicago, June 29-30, 2005.

Singh, J.P., B.E. Swanson and K.M. Singh (2005). Organizing and Linking Farmers with Markets: Experience of the NATP Project in India, presentation at the $15^{\text {th }}$ Annual World Food \& Agribusiness Symposium, Chicago, June 27, 2005.

Singh, J.P., Swanson, B.E and Singh K.M. (2005). Developing a Decentralized, MarketDriven Extension System in India: The ATMA Model. Good Practice Paper prepared for the World Bank, Washington DC.

Singh, J.P., Swanson, B.E. \& Singh, K.M. (2006). Developing a decentralized, marketdriven extension system in India: The ATMA model. In A.W. van den Ban and R.K. Samanta, eds. changing roles of agricultural extension in Asian nations, pp. 203-223. Delhi, B.R. Publishing.

Singh, K.M., B.E. Swanson and J.P. Singh (2005). Development of Supply Chains for Medicinal Plants: A Case Study Involving the Production of Vinca Rosa by Small Farmers in the Patna District of Bihar India, paper presented at the Workshop on Building New Partnerships in the Global Food Chain, Chicago, June 29-30, 2005

Singh, K.M; Meena, M.S; and Jha, A.K (2009). Impact assessment of agricultural extension reforms in Bihar, Indian. Res. J. Ext. Edu. 9 (2): 110-114.

Singh, K.M; Meena, M.S; and Jha, A.K (2011). Agricultural Innovations in IndiaExperiences of ATMA Model, Paper presented in International Conference on Innovative Approaches to Agricultural Knowledge Management: Global 
Extension Experiences from November 9-12, 2011 at NAAS New Delhi organized by International Society of Extension Education (INSEE).

Singh, K. M., Swanson, Burton E., Jha, A. K. and Meena, M. S. (2012). Extension Reforms and Innovations in Technology Dissemination-The ATMA Model in India (October 30, 2012). (Available at http://dx.doi.org/10.2139/ssrn.2168642)

Singh, K.M. and Meena, M. S., (2011). Agricultural Innovations in India-Experiences of ATMA Model (Available at SSRN: http://dx.doi.org/10.2139/ssrn.1989823)

Singh, K. M., and B. E. Swanson (2006). Developing a market-driven extension system in India. Proceedings of the 2006Annual Conference of the Association for International Agricultural and Extension Education (AIAEE) 22: 627-637.

Sulaiman, V.R. and Sadamate V.V. (2000). Privatizing agricultural extension in India. Policy Paper 10, National Centre for Agricultural Economics and Policy Research, New Delhi.

Swanson, B.E. (2006). The changing role of agricultural extension in a global economy. Journal of International Agricultural and Extension Education 13(3): 5-17.

Swanson, B.E. (2006). Extension Strategies for Poverty Alleviation: Lessons from China and India. Journal of Agricultural Education and Extension, 12(4): 285-299.

Swanson, B.E. (2008). Global review of good agricultural extension and advisory service practices. Rome: Food and Agriculture Organization of the United Nations.

Swanson, B.E. and Mathur, P. N. (2003). Review of the Agricultural Extension System in India, The World Bank, July 2003.

Swanson, B.E. (2008). FAO Report on global review of good agricultural extension and advisory service practices (http://www.fao.org/nr/ext/extn_en.htm).

Swanson, B.E. and R. Rajalahti. (2010). Strengthening Agricultural Extension and Advisory Systems. Washington, D.C. The World Bank. http://siteresources.worldbank.org/INTARD/Resources/Stren combined web.pdf

Tyagi, Y. and Verma, S. (2004). Economic rate of return of innovations in technology dissemination component of the National Agricultural Technology Project submitted to the MANAGE, Hyderabad, India, 2004.

Working Group on Agricultural Extension (2007). Recommendations of working group on agricultural extension for formulation of eleventh five-year plan (2007-12). New Delhi: Planning Commission.

World Bank (2004). Implementation completion report on a credit and a loan to India for the Diversified Agricultural Support Project. Report No. 29529. Washington, D.C.

World Bank (2005). Implementation completion report on a credit and a loan to India for the National Agricultural T 
